\title{
Research on Applied Personnel Training System Optimization of Tourism Management Specialty
}

\author{
Xiaoxuan Li \\ Fushun Teachers College, Fushun Liaoning 113122
}

Keywords: tourism management specialty; applied talents; personnel training; pattern optimization

\begin{abstract}
This paper tries to adhere to the student-oriented concept, meet the professional needs, highlight the practice of learning, and strengthen the principles of education and teaching from target system, curriculum system, methods, evaluation system and training environment. The five directions of optimizing the model system of talent training are put forward to provide scientific guidance for the training of applied talents of the tourism management specialty in our country.
\end{abstract}

\section{Introduction}

With the development of the tourism industry's increasingly mature, in order to meet the needs of the tourism industry to tourism management professional application of talent market demand for institutions of higher learning tourism management talent development capacity of the lift, Hubei University traveling development research institute's horse brave professor proposed take the curriculum module as the foundation, take the quality module, ability module as two wings " $2+1$ " the traveling management specialized application personnel training element can promote the pattern, But travels the managerial talent demand quality level facing the present high, the specialized ability strong, the level request depth, the profession transforms the quick characteristic, the university traveling management specialized application personnel training pattern also waits for further the optimization and the promotion.

\section{Guiding Ideology of Applied Personnel Training System Optimization of Tourism Management Specialty}

Huge demand raises which for the initiative adaptation higher education enterprise rapid development and the university traveling management professional, impels the education educational reform the further deepening and the teaching system innovation, promotes the student to study independently, trains the application traveling management professional.

In this foundation, proposes the university traveling management specialized application personnel training pattern system optimization guiding ideology: Implements earnestly carries out the spirit which the Ministry of Education Related University traveling managerial talent raises, take will travel the personnel market future development as the background, will positively set up the traveling profession application personnel training the scientific view, manifests educational model which the theoretical teaching, the practice teaching, the scientific research will unify, will raise the high quality, the strong ability application talented person [1], The promotion traveling management professional raises competitive power.

\section{Principle of Applied Personnel Training System Optimization of Tourism Management Specialty}

The union our country University traveling management professional raises the development at present the present situation, carries on the optimization to the traveling management specialized application personnel training pattern, should follow persisted humanist, the encompassment specialized demand, studies for the purpose of application three big principles prominently. 
Students are the centeral part of the talent training object, should adhere to the student as the main body, based on the students' level and their future career planning [2], according to their aptitude, and mobilize students' potential into full play and enthusiasm, to meet the needs of applied tourism management talents.

In the university personnel training process, should consider fully traveling management specialized demand characteristic, in view of its comprehensive nature strong, practicality strong, ability strong, professional strong demand characteristic, through the strengthened foundation, the prominent practice, promotion ability, improves the quality the way, quality, ability, curriculum three big module full fusion development, thus realization traveling management specialized application personnel training pattern system optimization.

Highlight the principle of applying learning to practical use

To develop the tourism management professional application of talent, should pay special attention to students practical ability and quality of basic training, so that they have learned, reflect the abilities and qualities are better equipped to adapt to the working environment, to meet the needs of the tourism market.

\section{Four General Orientations of Applied Personnel Training System Optimization of Tourism Management Specialty}

To achieve the university travel management professional applied personnel training mode the system optimization, it must be concluded, the consolidation of the experience and the results of the full mobilization of the forces of the Parties to enhance the implementation of the system interactive platform optimization, the optimization of personnel training, model run path optimization, four of the optimization work, thereby promoting our tourism management professional colleges and universities applied personnel training mode for further development.

"The State Council about Speeds up Tourism Development Opinion" the tourism localization for strategic pillar industry and people more satisfactory modern service industry, in view of its industrial pattern change and the development, the traveling personnel market demand also presents the new demand: The high service quality, strong adaptiveness, have the overall situation view, have keen.

In the establishment of the training of high-quality and high capacity applications, personnel training objectives of the curriculum module for conversion, multi-level, multi-stage, through the improvement and contribute to the achievement of tourism management professional talent development model for the development of breakthrough.

First, the elementary knowledge transformed type optimization. Above the foundation curriculum, should join the engineering course suitably the foundation curriculum, the solution traveling management specialized systematization thought defective question, causes the student through the liberal arts knowledge science subjects, the science subjects knowledge engineering course, will study the knowledge will carry on the system the conformity, thus promotion knowledge integration ability.

Second, quality module multi-layered suboptimization. The traveling management specialized application talented person, must have the quality may include: Strong physique, noble quality as well as professional accomplishment three stratification planes.

Third, practices the link the entire journey penetration. To fully benefit from foreign tourism management combining production and research and development experience [ 3], Practical exercises will be distributed to each semester, or even every door-based professional lesson to enable students at the completion of a theory course, can immediately in practice to exercise, not only for the "learned", to have learned also play a role in the consolidation.

In the modern tourism management specialty talented person training method, should take the transformation teacher and student role as the focal point, causes between the teacher and student "the actor and the audience" the relation to "the director and the actor" transforms. The student achievement "the actor", take the textbook in knowledge as "the script", prepares a lesson, the classroom after the class in front of trains four step ways which, the class recess exchange, the class 
expands, completes the knowledge independently, the visualization, thorough, gives moral guidance highly effective into, stimulates the student to participate in the study the enthusiasm, is advantageous for the student well understanding and the grasping knowledge utilization.

The personnel training pattern implementation effect appraised, efficiently in personnel training appraisal system construction consummation, rationality and scientific nature. Based on the improvement of teaching quality, so as to improve the quality of tourism management personnel training, so that students can overcome the structural differences in market and adapt to the demand of the dynamic tourism talent market smoothly, it is possible to optimize the evaluation system by renewing the evaluation idea, perfecting the evaluation elements and innovating the evaluation methods.

\section{Conclusion}

The country by only then stands, industry by only then is popular, the high level talented person is the strategic industrial determining factor. In tourism development is becoming more and more mature now, through the tourism management system optimization of cultivating applied talents, cultivating applied talents of high quality and strong ability, become a professional tourism management talents in colleges and universities reform, one of the important ways to practice education system reform and the construction of higher education in our country power play an important role.

\section{Acknowledgment}

Fund project: "construction and practice of high vocational college tourism professional group" s upported by the educational department of Liaoning province. (Project No. 2009164)

\section{References}

[1] Jiao Ai li. A study on the pattern of tourism higher education in China based on the interactive relationship between tourism industry and higher education [D]. Liaoning Normal University, 2008:7-8.

[2] Ma Yong, Wei Wei, Tang Mei. Bearing in mind that the tourism management professional talent development model to build and implement impact assessment [J]. Tourism Studies journal • Human Resources Management Special Issue, 63.

[3] Yu Ping. Our country University can unfold the traveling education the extant question and the optimized countermeasure studies [D]. Liaoning Normal University, 2008:16-17.

[4] htp://baike.baidu.com/view/56734.htm\#4:20l-3 -15. 